\title{
Design and Development of SECI and Moodle Online Learning Systems to Enhance Thinking and Innovation Skills for Higher Education Learners
}

\author{
https://doi.org/10.3991/ijet.v13i03.7991 \\ Suparoek Chootongchai ${ }^{\bowtie}$ ), Noawanit Songkram \\ Chulalongkorn University, Bangkok, Thailand \\ Suparoek.c@ehula.ac.th
}

\begin{abstract}
This study aimed to design and develop an online learning system to enhance thinking and innovation skills for higher education learners. The objectives were to (1) design a system diagram, system architecture and functional structure for online learning framed by the SECI process (Socialization, Externalization, Combination and Internalization) and Moodle, (2) develop an online learning management system (LMS) with a new plug-in using Moodle, and (3) evaluate system suitability for the development of students' thinking and innovation skills. The research methodology was developed using a literature review to identify core components, focus group interviews to verify the process, software development by Moodle LMS, and assessments to measure learning outcome. Research instruments consisted of interview questions, Moodle LMS, and a self-assessment questionnaire. Assessment data was evaluated through pre-test and post-test analysis. Results revealed a statistically significant difference between pre- and post-test scores in both thinking and innovation skills, with the post-test score higher than pre-test score at a 0.01 level of significance. Findings revealed that online learning systems had a positive influence on students' thinking and innovation skills.
\end{abstract}

Keywords-online learning system, SECI process, Moodle LMS

\section{Introduction}

Institutions of higher education have increasingly provided online learning [1]. In the United States, there are now over six million students (nearly a third of the total) enrolled for at least one online course [2]. The online learning process is conducted by students and teachers who communicate and interact with course content via internetbased learning technology [3]. Online learning has several advantages over the traditional classroom by providing accessibility and flexibility $[4,5]$. Students can more easily search information from learning resources with increased flexibility to study at any time and in any place $[6,7]$.

To achieve learning for higher education, students need to have a range of thinking and innovation skills (i.e., critical thinking, creativity, collaboration, and communication) if they wish to be successful in work and life, often referred to as " 21 st century 
skills." $[8,9]$. Therefore, it is important to design and develop online learning systems which enhance these skills. This process has gained more attention from researchers, and there are now many high-quality publications to encourage online teaching techniques in the classroom [10].

There are many benefits from the use of online learning to enhance thinking and innovation skills which can enable students to acquire the values of knowledge sharing and knowledge co-creation in open communities without time and place constraints through exchanging ideas, sharing thoughts, and exploring information together. Researchers also determined that current students in higher education were mostly satisfied with this type of learning because they can play key roles as content creators that are shared through the online learning environment, while teachers' roles shift to coaches, resource-advisors, and motivators [11].

Applications of these thinking and innovation skills are in line with a strong demand growth in global patent requirements, and 2.9 million new patent applications were filed worldwide in 2015 (Fig. 1), up 7.8\% from 2014 [12].

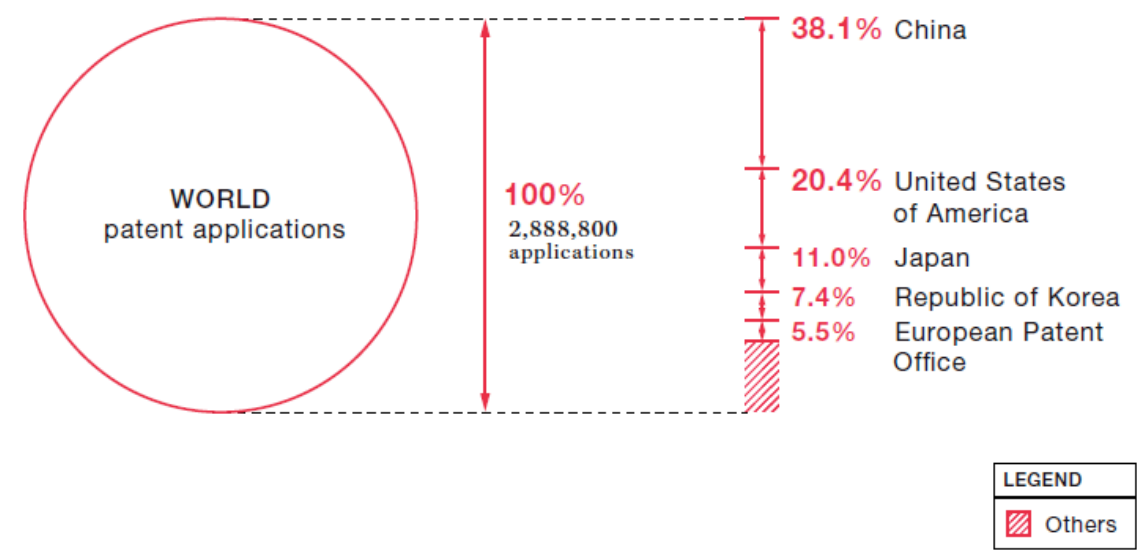

Fig. 1. Total patent applications from the WIPO Statistics Database, October 2016 [12]

A sense of willingness is required to continue learning far beyond the years of formal education. Learning institutions should, therefore, adapt quickly to improve educational outcomes and promote a more prepared workforce by developing skills such as critical thinking, insight, and analysis capabilities including experimental learning to collaborate, work in groups and respond adaptively [13-16].

Countless surveys and studies have shown an increasing number of individuals, corporations and institutions turning to online learning as it is effective and convenient [17]. Online headcounts increased by about 30\% between 2011 and 2015, the number of online programs grew by $110 \%$, and the number of schools embracing online learning increased by more than $130 \%$ (Fig.2) [18]. The internet continues to develop and evolve, offering ever more advanced technology for online learning techniques.

Recent research by Docebo LMS forecasting online learning technology for 2017$2021[19]$. 


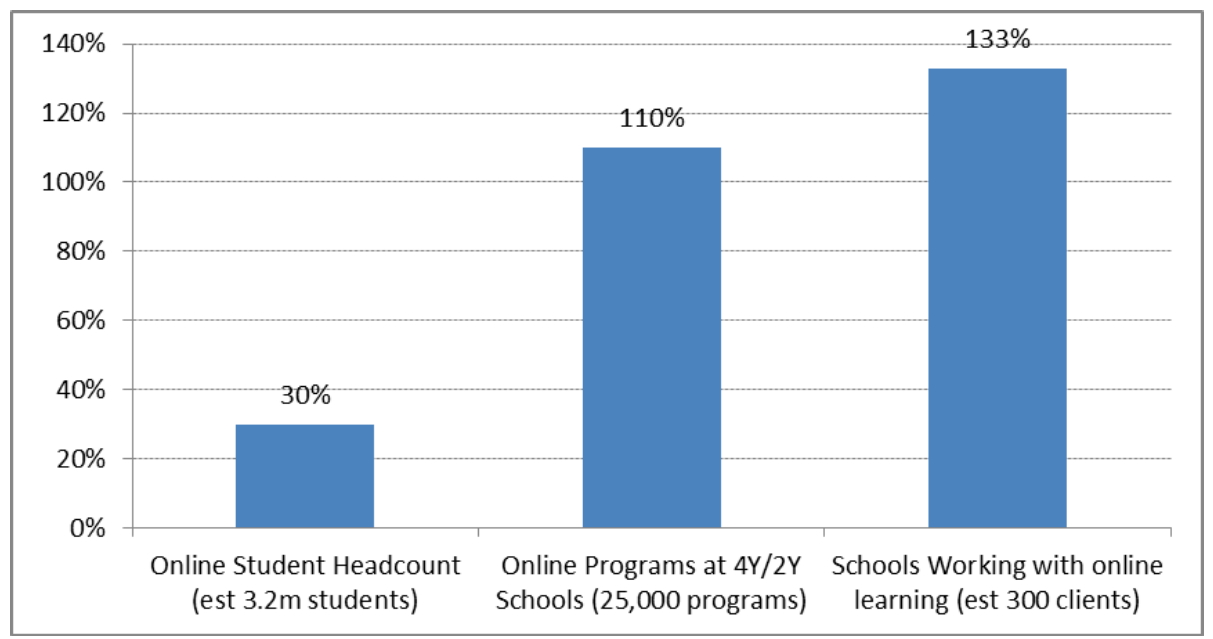

Fig. 2. Online higher education percentage growth, 2011-2015

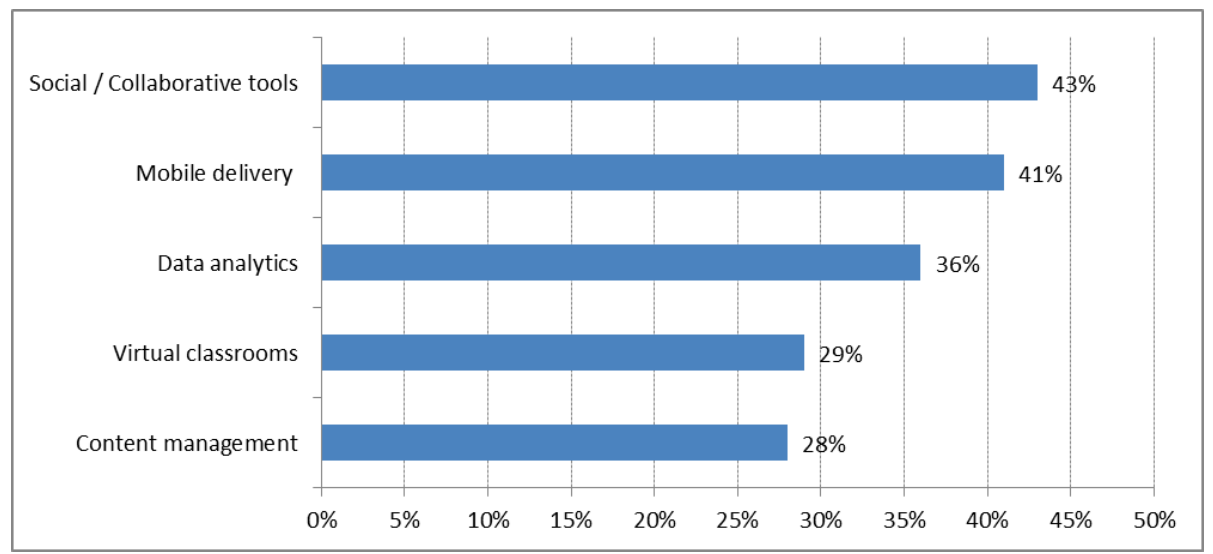

Fig. 3. Top five learning technology priorities

Social or collaborative tools in Fig. 3 are the most considered technology because they leverage interaction and allow students to think, explore, and offer input on the subject matter through effective use of communication. Relevant and authentic learning activities are the most likely to succeed.

The design and development of online learning systems enhance thinking and innovation skills for higher education learners, offering great potential to facilitate skill growth. However, little is known regarding how systems influence skill acquisition. This paper presents an online learning system with a new plug-in developed by Moodle LMS and evaluates its suitability through pre-test and post-test data analysis using research and development (R\&D) methodology. A better understanding of the mechanisms of online collaborative learning will allow the development of effective systems to facilitate and enhance thinking and innovation skills. 


\section{$2 \quad$ Literature review}

\subsection{Design of online learning using the SECI process to enhance thinking and innovation skills}

Online learning systems have technology-enhanced designs and features to support all forms of educational activities, not only to connect remote students but also to employ automation to shape face-to-face interactions [20]. The spiral of knowledge creation (SECI process) significantly involves both thinking and innovation skills [21]. The SECI process, theorized by Nonaka and Takeuchi [22], implies that personal knowledge, experience, skills, and expertise can create innovation and development of new products [23-25]. There are two kinds of knowledge: tacit knowledge and explicit knowledge. Tacit knowledge is subjective, highly personal, and insightful and difficult to share with others. Explicit knowledge can be expressed in formal, systematic language and shared in the form of data. These two kinds of knowledge are created and transferred in four different phases by the SECI process (Fig. 4).

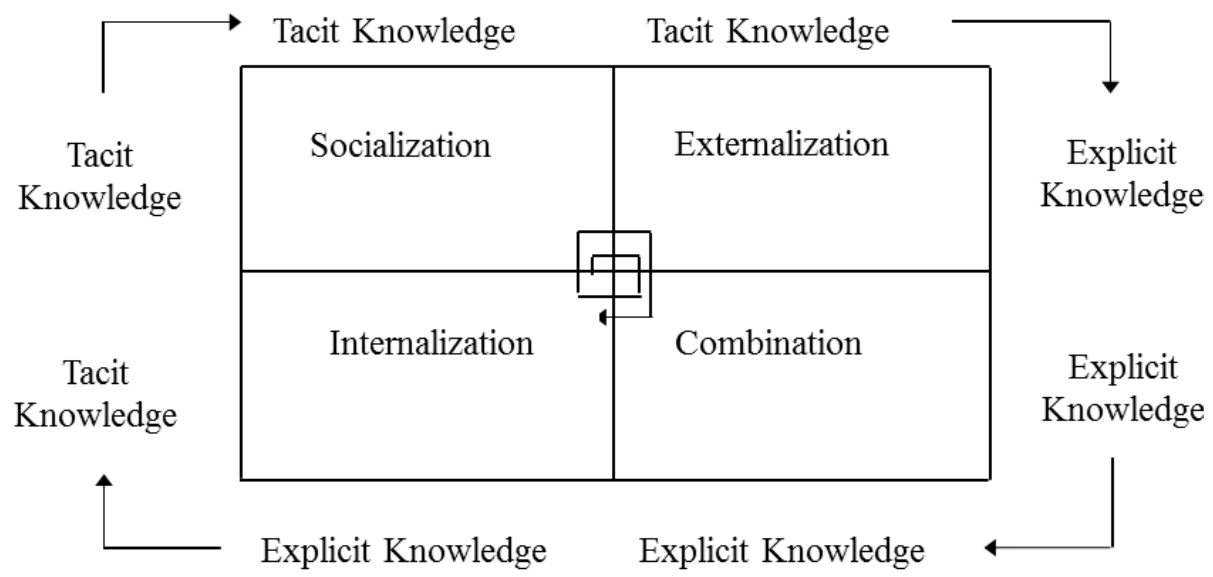

Fig. 4. The SECI process [22]

The SECI process identified four modes of knowledge conversion as Socialization (from individual tacit knowledge to group tacit knowledge), Externalization (from tacit knowledge to explicit knowledge), Combination (from separate explicit knowledge to systemic explicit knowledge), and Internalization (from explicit knowledge to tacit knowledge). This process is fundamentally important because it is one of the few approaches that focuses on the interaction between tacit and explicit knowledge for innovation based learning [26, 27].

To find proper system components, multiple sources of literature were reviewed by synthesizing components through knowledge creation mechanisms (SECI process). Selection was influenced by components that were the most similar.

In the detailed "Socialization" synthesis (Table 1), the components formed the primary source. The most similar outputs were online discussion, social community, IM 
(Instant Message), video conference, virtual class, telephone, interactive learning, web 2.0 platform, email, log file system, wikis and collaborative writing tools.

From Table 1, the concept of online discussion was selected to develop a system to enhance thinking and innovation skills.

In the detailed "Externalization" synthesis (Table 2), the components formed the primary source. The most similar outputs were wikis, blogs, IM (Instant Message), $\mathrm{VoIP} /$ phone, email, online discussions, collaborative working, video conferencing, tag, conceptual modeling tool, mobile technology, metadata, PLE, word editor, R\&D encyclopedia service, external interactive learning, discussion forums, repository of shared documents, social networks, property tools, discourse systems, electronic resources, LMS and discussion forum.

Table 1. Synthetic technologies through the SECI process under Socialization

\begin{tabular}{|c|l|c|l|}
\hline No. & \multicolumn{1}{|c|}{ Technology } & Number of citations & \multicolumn{1}{c|}{ Researchers } \\
\hline 1. & online discussion & 6 & {$[28],[29],[30],[31],[32],[33]$} \\
\hline 2. & social community & 5 & {$[30],[33],[34],[35],[36]$} \\
\hline 3. & IM (Instant Message) & 5 & {$[28],[32],[33],[34],[37],[38]$} \\
\hline 4. & video conference & 4 & {$[34],[28],[36],[38]$} \\
\hline 5. & virtual class & 2 & {$[29],[32]$} \\
\hline 6. & telephone & 2 & {$[36],[39]$} \\
\hline 7. & interactive learning & 1 & {$[40]$} \\
\hline 8. & web 2.0 platform & 1 & {$[36]$} \\
\hline 9. & e-mail & 1 & {$[39]$} \\
\hline 10. & log file system & 1 & {$[40]$} \\
\hline 11. & wikis & 1 & {$[41]$} \\
\hline 12. & collaborative writing tools & 1 & {$[41]$} \\
\hline
\end{tabular}

Table 2. Synthetic technologies through the SECI process under Externalization

\begin{tabular}{|c|l|c|l|}
\hline No. & \multicolumn{1}{|c|}{ Technology } & Number of citations & \multicolumn{1}{c|}{ Researchers } \\
\hline 1. & wikis & 5 & {$[31],[33],[35],[41],[42]$} \\
\hline 2. & blogs & 5 & {$[33],[35],[38][41],[42]$} \\
\hline 3. & IM (Instant Message) & 3 & {$[35],[36],[42]$} \\
\hline 4. & VoIP/phone & 3 & {$[35],[36],[39]$} \\
\hline 5. & email & 3 & {$[35],[36],[39]$} \\
\hline 6. & online discussions & 2 & {$[30],[31]$} \\
\hline 7. & collaborative working & 2 & {$[37],[41]$} \\
\hline 8. & video conferencing & 2 & {$[35],[36]$} \\
\hline 9. & tag & 2 & {$[35],[36]$} \\
\hline 10. & conceptual modeling tool & 1 & {$[30]$} \\
\hline 11. & mobile technology & 1 & {$[35]$} \\
\hline 12. & metadata & 1 & {$[35]$} \\
\hline 13. & PLE & 1 & {$[35]$} \\
\hline 14. & word editor & 1 & {$[32]$} \\
\hline
\end{tabular}




\begin{tabular}{|l|l|l|l|}
\hline 15. & R\&D encyclopedia service & 1 & {$[43]$} \\
\hline 16. & external interactive learning & 1 & {$[40]$} \\
\hline 17. & discussion forums & 1 & {$[42]$} \\
\hline 18. & repository of shared documents & 1 & {$[41]$} \\
\hline 19. & social networks & 1 & {$[41]$} \\
\hline 20. & property tools & 1 & {$[41]$} \\
\hline 21. & discourse systems & 1 & {$[41]$} \\
\hline 22. & electronic resources & 1 & {$[29]$} \\
\hline 23. & LMS & 1 & {$[29]$} \\
\hline 24. & discussion forum & 1 & {$[29]$} \\
\hline
\end{tabular}

From Table 2, the concept of wikis was selected to develop a system to enhance thinking and innovation skills.

In the detailed "Combination" synthesis (Table 3), the components formed the primary source. The most similar outputs were knowledge base, search engines, ecollaborative systems, wikis, tags, bookmarks, social networks, RSS, email, mashups, blogs, internet, conceptual modeling tool, reflective analysis tool, pod/vodcasting, PLE, SNA, rating, filtering, recommendations, reviews, telephones, project presentation, property tools, discourse systems and LMS.

Table 3. Synthetic technologies through the SECI process under Combination

\begin{tabular}{|c|c|c|c|}
\hline No. & Technology & Number of citations & Researchers \\
\hline 1. & knowledge base & 5 & {$[28],[29],[32],[38],[41]$} \\
\hline 2. & search engines & 4 & {$[28],[35],[39],[42]$} \\
\hline 3. & e-collaborative systems & 3 & [39], [41], [42] \\
\hline 4. & wikis & 3 & {$[31],[35],[41]$} \\
\hline 5. & $\operatorname{tags}$ & 3 & {$[33],[35],[36]$} \\
\hline 6. & bookmarks & 3 & {$[33],[35],[36]$} \\
\hline 7. & social networks & 2 & {$[32],[41]$} \\
\hline 8. & RSS & 2 & {$[35],[36]$} \\
\hline 9. & email & 2 & {$[32],[39]$} \\
\hline 10. & mashups & 2 & {$[35],[36]$} \\
\hline 11. & blogs & 2 & {$[35],[41]$} \\
\hline 12. & internet & 2 & {$[32],[39]$} \\
\hline 13. & conceptual modeling tool & 1 & {$[30]$} \\
\hline 14. & reflective analysis tool & 1 & {$[30]$} \\
\hline 15. & pod/vodcasting & 1 & {$[35]$} \\
\hline 16. & PLE & 1 & {$[35]$} \\
\hline 17. & SNA & 1 & {$[35]$} \\
\hline 18. & rating & 1 & {$[35]$} \\
\hline 19. & filtering & 1 & {$[35]$} \\
\hline 20. & recommendations & 1 & {$[35]$} \\
\hline 21. & reviews & 1 & {$[35]$} \\
\hline 22. & telephones & 1 & [39] \\
\hline
\end{tabular}




\begin{tabular}{|c|l|l|l|}
\hline 23 & project presentation & 1 & {$[37]$} \\
\hline 24. & property tools & 1 & {$[41]$} \\
\hline 25. & discourse systems & 1 & {$[41]$} \\
\hline 26. & LMS & 1 & {$[29]$} \\
\hline
\end{tabular}

From Table 3, the concept of knowledge base was selected to develop a system to enhance thinking and innovation skills.

In the detailed "Internalization" synthesis (Table 4), the components formed the primary source. The most similar outputs were knowledge base, wikis, Q\&A, simulation, structural design software, reflective analysis tool (IVT), community building tool (ASAP web conference software), multi-player gaming, RSS, virtual design tools, workflow systems, LMS and discussion forum.

From Table 4, the concept of knowledge base was selected to develop a system to enhance thinking and innovation skills.

Table 4. Synthetic technologies through the SECI process under Internalization

\begin{tabular}{|c|l|c|l|}
\hline No. & \multicolumn{1}{|c|}{ Technology } & Number of citations & \multicolumn{1}{|c|}{ Researchers } \\
\hline 1. & knowledge base & 4 & {$[29],[32],[43],[39]$} \\
\hline 2. & wikis & 2 & {$[36],[41]$} \\
\hline 3. & Q\&A & 2 & {$[37],[43]$} \\
\hline 4. & simulation & 2 & {$[35],[36]$} \\
\hline 5. & structural design software & 1 & {$[32]$} \\
\hline 6. & reflective analysis tool (IVT) & 1 & {$[30]$} \\
\hline 7. & community building tool (ASAP & 1 & {$[30]$} \\
\hline 8. & meb conference software) & 1 & {$[35]$} \\
\hline 9. & RSS & 1 & {$[33]$} \\
\hline 10. & virtual design tools & 1 & {$[32]$} \\
\hline 11. & workflow systems & 1 & {$[32]$} \\
\hline 12. & LMS & 1 & {$[29]$} \\
\hline 13 & discussion forum & 1 & {$[29]$} \\
\hline
\end{tabular}

\subsection{Development of an online learning system using Moodle to enhance thinking and innovation skills}

With over 85 million users, Moodle is the world's leading open source Learning Management System (LMS) [44]. Moodle is implemented as a platform for sharing information and conducting online learning. Teachers can also improve the Moodle platform by implementing plug-ins to enhance students' collaborative thinking and innovation skills. Strong evidence suggests that students can increase their learning skills through using Moodle [45].

To develop an online learning system in line with the selections of synthetic technologies in the previous section, focus group interviews were conducted and the relevant activities, blocks and resources from Moodle LMS were listed as shown in Table 5. 
Table 5. Activities blocks and resources for Moodle

\begin{tabular}{|l|l|l|}
\hline \multicolumn{1}{|c|}{ Activities } & \multicolumn{1}{c|}{ Blocks } & \multicolumn{1}{c|}{ Resources } \\
\hline - Forum & - Checklist & Book \\
- Chat & - Wikipedia & . File \\
- Advance Mindmap & - Search forums & . Folder \\
- WigBlueButtonBN & - Blog Menu & Label \\
- Checklist & - Blog tags & Page \\
- Workshop & & \\
- Database & & \\
- Stamp collection & & \\
- Badge & \\
- Grading & \\
- Certificate & \\
\hline
\end{tabular}

The design and development should incorporate the technologies mentioned above. In summary, the success of an online learning system which enhances thinking and innovation skills consists of three major facets: (1) technology to exchange knowledge (2) technology to create knowledge, and (3) technology to discover knowledge.

\section{Objectives}

1. To design a system diagram, system architecture and functional structure for an online learning system framed by the SECI process and Moodle

2. To develop an online learning system with a new plug-in using Moodle LMS

3. To evaluate the system suitability for the development of students' thinking and innovation skills

\section{Hypothesis}

When the online learning system has been completed students in higher education will have enhanced and improved thinking and innovation skills.

\section{Scope of study}

1. Group interviews were conducted with five experts from educational institutes with expertise in educational technology.

2. The tools used were developed by Moodle LMS.

3. The samples consisted of 65 students undertaking bachelor education in 4-year university degree programs who completed the innovation skill course. 


\section{$6 \quad$ Research method}

Based on the constructivist theory [46-49], students should be the center of learning. Online learning systems can develop skills in several ways through creating a proper learning environment without time-and-place constraints, providing continuous information resources, and supporting learning by evaluation. Research methods employed to design and develop an online learning system to enhance thinking and innovation skills are listed in Table 6.

Table 6. Summary of research methods

\begin{tabular}{|l|l|}
\hline \multicolumn{1}{|c|}{ Research objective } & \multicolumn{1}{c|}{ Research method } \\
\hline $\begin{array}{l}\text { 1.To design a system diagram, system architecture } \\
\text { and functional structure for an online learning sys- } \\
\text { tem framed by the SECI process and Moodle }\end{array}$ & $\begin{array}{l}1.1 \text { Review the literature } \\
1.2 \text { Focus group interviews } \\
1.3 \text { Design the system diagram, system architecture } \\
\text { and functional structure }\end{array}$ \\
\hline $\begin{array}{l}\text { 2.To develop an online learning system with a new } \\
\text { plug-in using Moodle LMS }\end{array}$ & $\begin{array}{l}\text { 2.1 Develop Moodle plug-in } \\
\text { 2.2 Develop the system }\end{array}$ \\
\hline $\begin{array}{l}\text { 3. To evaluate the system suitability for the devel- } \\
\text { opment of students' thinking and innovation skills }\end{array}$ & 3.3 Perform the pre-test and post-test \\
\hline
\end{tabular}

\section{$7 \quad$ Data collection for system design}

The data collection was designed using a literature review and focus group interviews focusing on online learning perspectives to enhance thinking and innovation skills. Focus group interviews were conducted for 2 hours approximately. All questions were open-ended and designed to encourage participants to freely describe their own thoughts within each topic area. All interviews were taped and transcribed. The interviewers were five experts who had at least 20 years' practical experience in educational technology. The frequency of particular or similar statements was considered important for the system design.

\section{$8 \quad$ System design}

The researcher studied, analyzed, and synthesized the interview data and relevant documents from the literature review to design an online learning system that could be applied to enhance thinking and innovation skills for higher education learners.

\subsection{System diagram}

Results from the data collection suggested that the online collaborative learning process represented activities and responsibilities among students and teachers shown in Fig. 5. The process starts with project discussion (Inspiration) to understand the topic by brainstorming, followed by state of knowledge contribution (Idea selection) to develop the solution by wiki, state of project implementation (Invention) by a 
workshop, and finally the state of assessment (Operation). Additionally, there is a knowledge base for after action review and post-project review. This supports students and teachers regarding lessons learned and best practice.

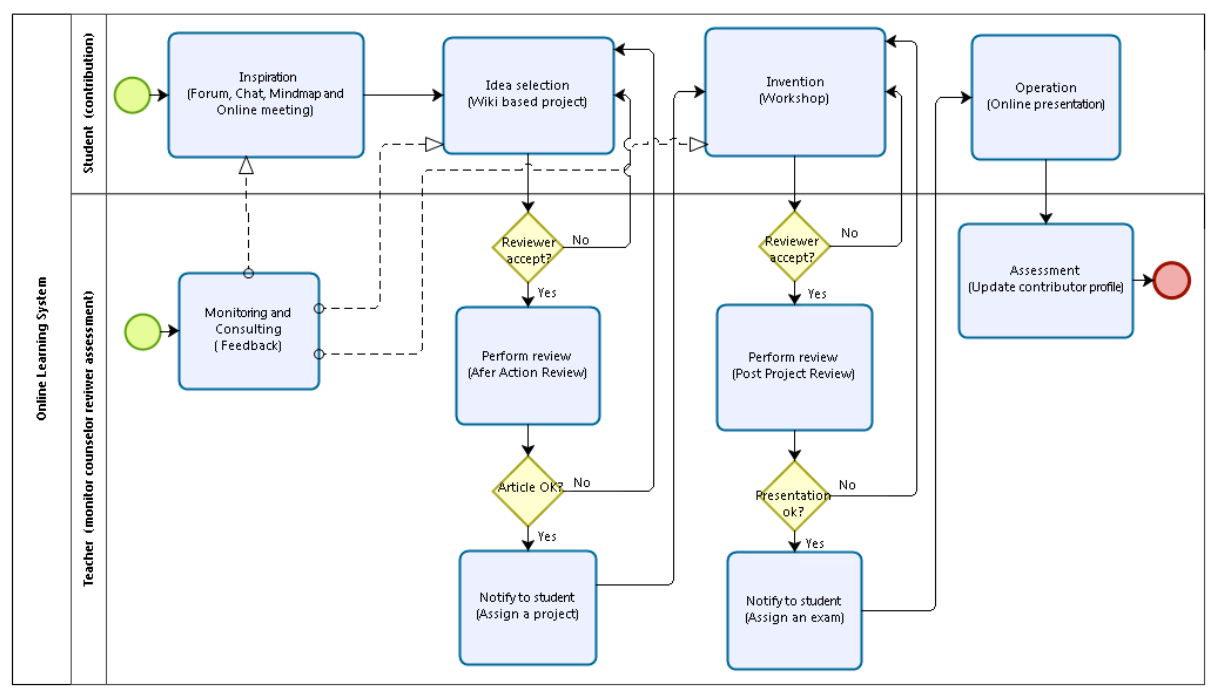

Fig. 5. System diagram

Two types of users are defined.

- Teachers are responsible for managing the structure and contents of the system (add/edit the contents, add/edit the documents, add/edit the worksheets), and also view students' data to monitor, consult, review and assess the project (add/delete/edit the students' data, add/edit the project scores).

- Students are responsible for studying their lesson contents, accessing their learning resources, performing their instructional activities, and presenting their assigned projects.

\subsection{System architecture}

The architecture of the online learning system in Fig. 6 displays the components and operation layers that enhance thinking and innovation skills. The developed architecture of the online learning system consists of six major modules:

1. Interaction and communication module. This exchanges information from Forums, Chats, Mindmaps and Online meetings. High-accuracy, stability and safety of information exchange are the key success factors of online learning.

2. Collaborative learning module. This conducts online learning activities as collaboration. Collaboration between teachers and students is a key concern such as Wiki and Workshop. 
3. Learning resources module. This provides information and location of learning topics according to the teachers' requirements. Reliability of information and location are key determining components of learning resources.

4. Presentation module. This contributes to project presentation. Sharing experiences and giving feedback are key points for good presentation.

5. Motivation module. This explores and encourages students' competition. Gamification is a key design technique which includes games in learning environments such as Level up and Badge.

6. Evaluation module. This assesses students' learning of thinking and innovation skills. The Inno Ed Tool is the key primary plug-in including checklist and grading.
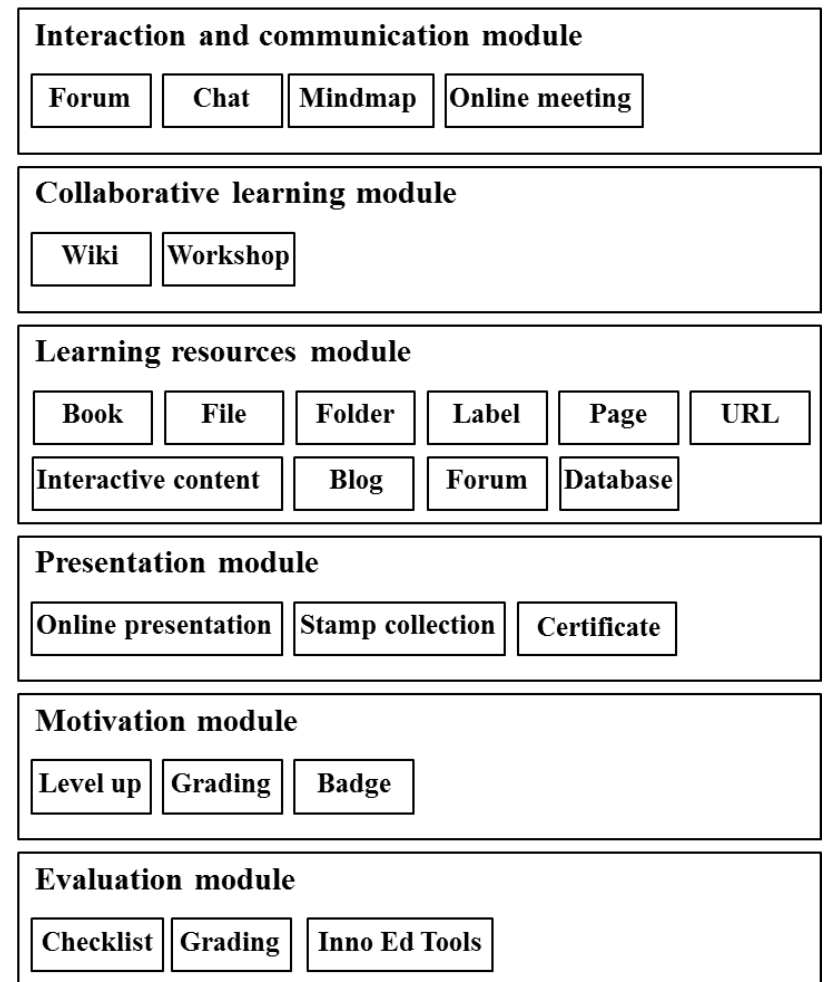

Fig. 6. System architecture

\subsection{Functional structure}

The components of the functional structure of an online learning system to enhance thinking and innovation skills include (1) activities in knowledge sharing, (2) activities in knowledge co-creation, (3) activities in project teamwork, and (4) activities in project presentation. The characteristics of the four activities of online learning system are shown in Table 7. 
Paper-Design and Development of SECI and Moodle Online Learning Systems to Enhance Thinking ...

Table 7. Characteristics of the four activities of an online learning system to enhance thinking and innovation skills

\begin{tabular}{|l|l|l|}
\hline Learning process & \multicolumn{1}{|c|}{ Activity } & \multicolumn{1}{|c|}{ Characteristic } \\
\hline 1.Inspiration & $\begin{array}{l}\text { Activities in knowledge } \\
\text { sharing }\end{array}$ & $\begin{array}{l}\text { Ability to study learning resources, search relevant data } \\
\text { from the literature and share ideas by brainstorming }\end{array}$ \\
\hline 2.Idea selection & $\begin{array}{l}\text { Activities in knowledge co- } \\
\text { creation }\end{array}$ & $\begin{array}{l}\text { Ability to construct the best project topic by drafting or } \\
\text { making a storyboard to plan and design the project }\end{array}$ \\
\hline 3.Invention & $\begin{array}{l}\text { Activities in project team- } \\
\text { work }\end{array}$ & $\begin{array}{l}\text { Ability to take step-by-step actions corresponding to } \\
\text { workshop processes to achieve the expected outcome }\end{array}$ \\
\hline 4.Operation & $\begin{array}{l}\text { Activities in project presenta- } \\
\text { tion }\end{array}$ & $\begin{array}{l}\text { Ability to publish the project, improve the project } \\
\text { through feedback and evaluate the work result }\end{array}$ \\
\hline
\end{tabular}

\section{System development}

The online learning system designed and developed by Moodle LMS is a web application hosted on servers of educational institutes (Fig. 7). The system uses PHP scripting language and the MySQL database. Users can access it through internet web browsers.

The software packages in Table 8 have a three-section structure as Server, Learning Management System (LMS), and URL. The Database server and Web server store various kinds of data and manage each application module in the system. Students and teachers can access LMS applications through internet browsers. The URL is a linkage to enter the learning module.

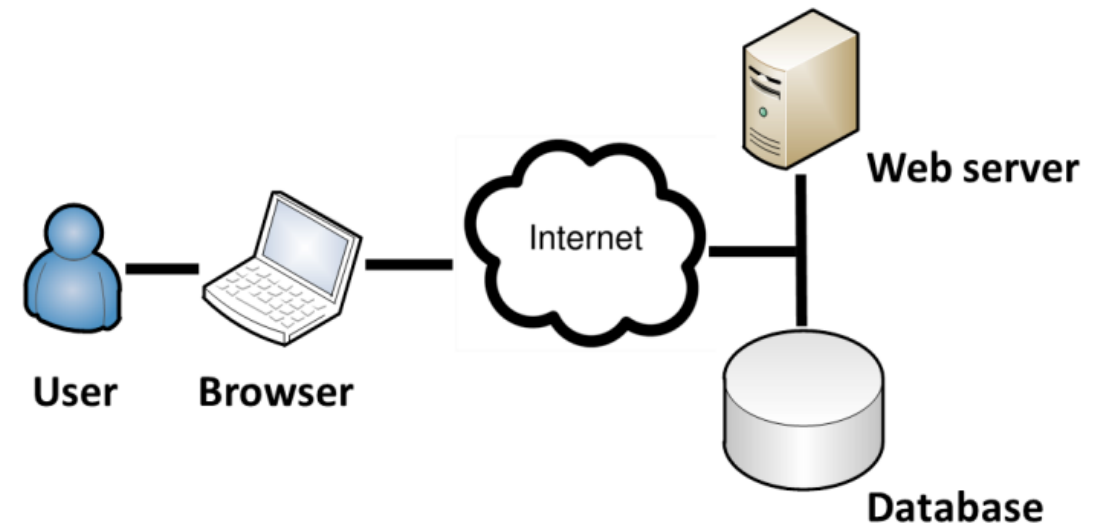

Fig. 7. System development

Table 8. Software packages of Moodle-based online learning systems

\begin{tabular}{|l|l|}
\hline \multicolumn{1}{|c|}{ Item } & \multicolumn{1}{c|}{ Description } \\
\hline Server & Linux + Apache + PHP + MySQL \\
\hline LMS & Moodle version 3.1 x \\
\hline URL & http://edtech.edu.chula.ac.th/research/innovation/INNOEDTOOLS/ \\
\hline
\end{tabular}




\subsection{Moodle plug-in development}

To evaluate students' skills in thinking and innovation requires the implementation of a smart agent for Moodle named "Inno Ed Tools" that allows teachers and students to view performance reports. A sample of source code is shown in Fig. 8 below as a screenshot.

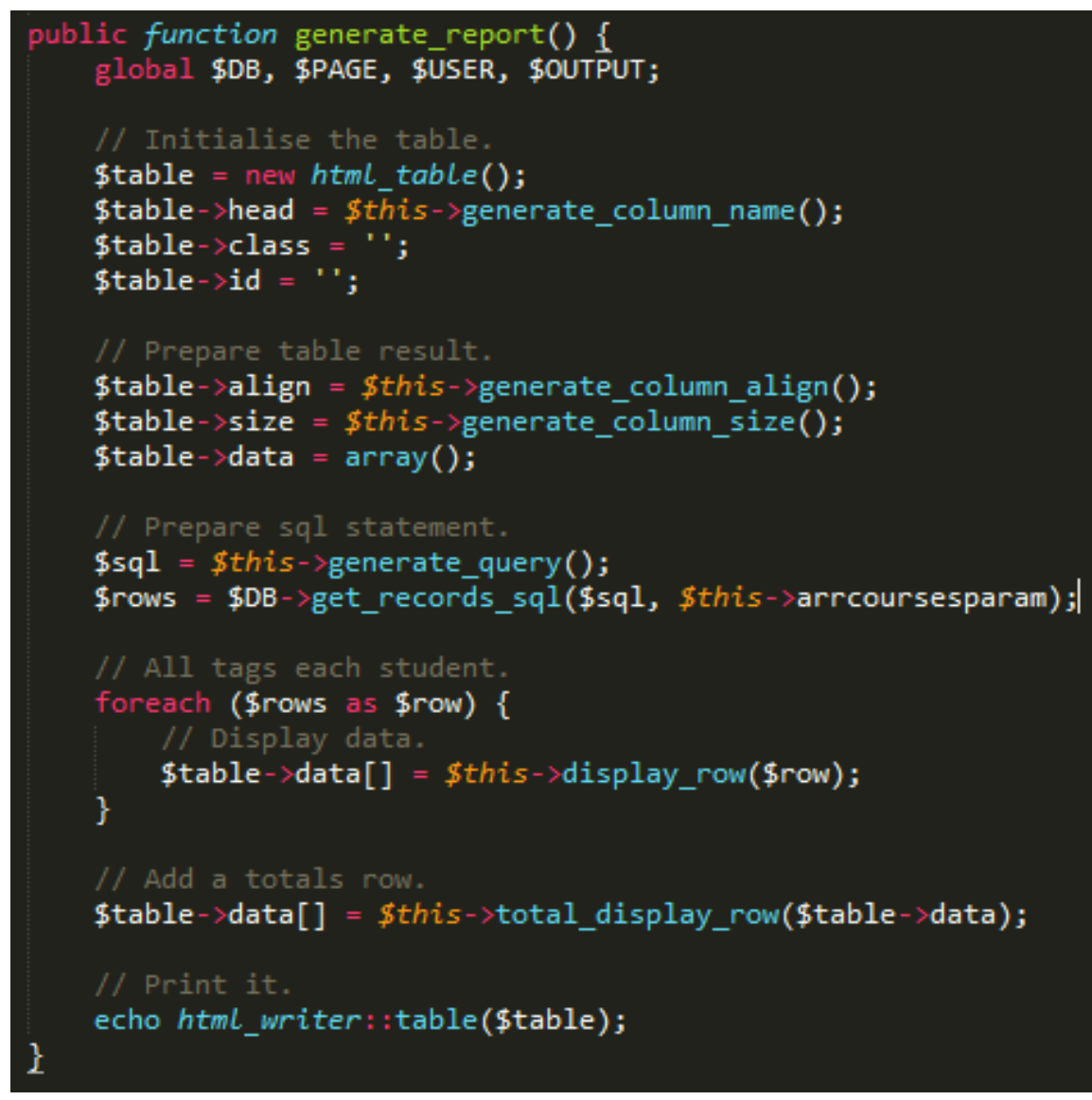

Fig. 8. Source code of Moodle's plug-in

The reports are created by the public function "generate_report ( )" to display statistical data of all enrolled students. These data are retrieved from SQL by the function "generate_query( ()" and then categorized into a table by the functions of "html_table ( )", "generate_column_name( )", generate_column_align( ), and generate_column_size ( ) .

This plugin allows users to collect statistics as standard tags retrieved from the blog entry in each course, and then displays the results in a summary report. Users can export data to a PDF document. The plug-in is now available at https://moodle.org/plugins/loc al innoedtools. 


\subsection{Moodle course development}

This study exhibits system implementation of online learning by Moodle LMS to enhance the collaborative learning process. There are four integrated phases as detailed in Fig. 9 below.

1. Inspiration: Students can study course materials and access knowledge sharing tools to brainstorm among members. Interactive video, Forum, Chat, Mindmap and Online meetings support collaborative learning and generate inspiration.

2. Idea selection: Students can build knowledge co-creation and select the best by wiki-based projects.

3. Invention: Students can develop their projects through workshops which enable the collection, review, and assessment of project work.

4. Operation: Students can present their projects and obtain feedback from relevant parties through online presentation.

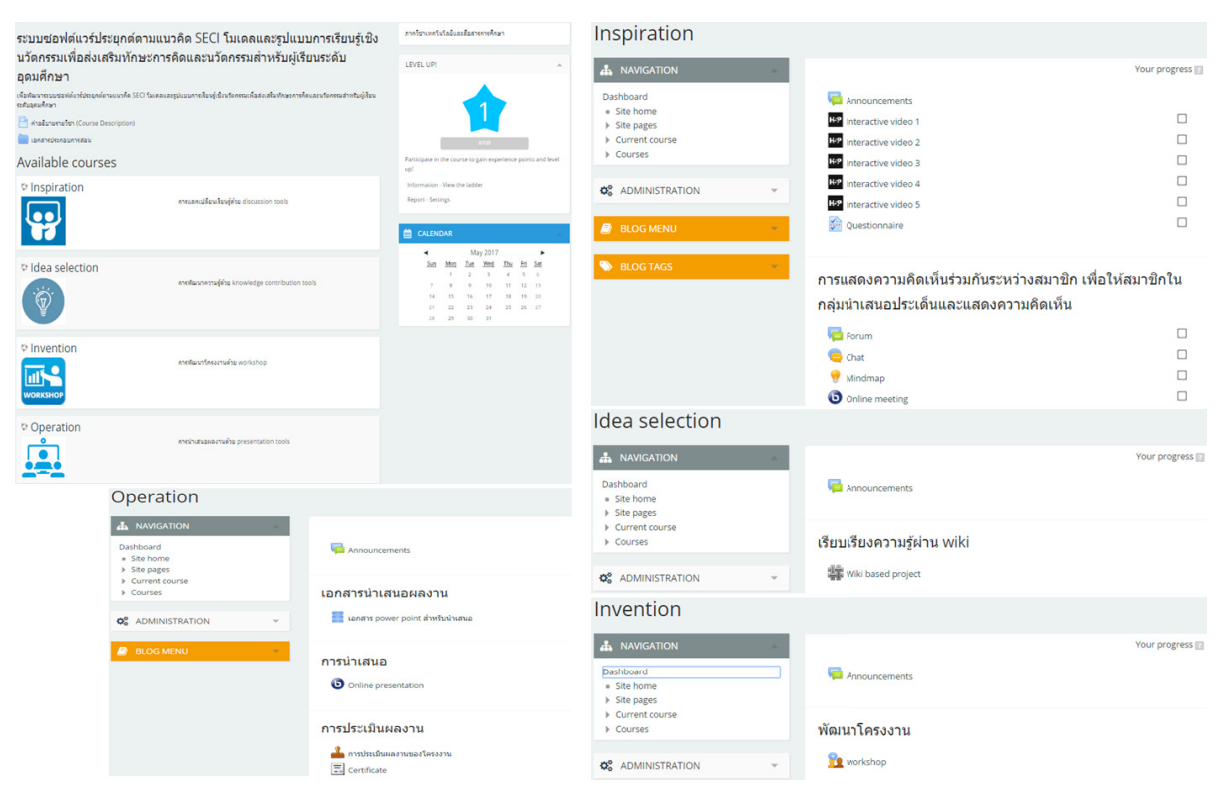

Fig. 9. Screenshots of the Moodle-based online learning system

To enhance interaction, motivation, and engagement with the proposed system, techniques of gamification are applied to the learning process such as Stamp collection, Level up and Badge.

\section{System evaluation}

After the design and development were complete, the researcher evaluated system suitability to ensure the realization of practical usage. An evaluation was made to 
assess the efficiency of students' thinking and innovation skill development. The sample consisted of 65 students undertaking bachelor education in 4-year university degree programs who completed the innovation skills course.

Comparison between skills in thinking and innovation was analyzed before and after study through the online learning system by average scores $(\overline{\mathrm{x}})$ and standard deviation (S.D.). Results showed that students' scores before studying were $3.06 \overline{\mathrm{x}}$ for skills in thinking and innovation with S.D. at 0.71. After studying, students' scores were $4.10 \overline{\mathrm{x}}$ with S.D. at 1.05 calculated by dependent t-test with a 0.01 level of significance $(\mathrm{t}=9.36)$ (Table 9).

Table 9. Comparison between pre- and post-test assessment scores of thinking and innovation skills

\begin{tabular}{|l|c|c|c|c|}
\hline \multicolumn{1}{|c|}{ Assessment } & $\mathbf{n}$ & $\overline{\mathbf{x}}$ & S.D. & t \\
\cline { 1 - 4 } Pre-test & 65 & 3.06 & 0.71 & \multirow{2}{*}{9.36} \\
\hline Post-test & 65 & 4.10 & 1.05 & \\
\hline
\end{tabular}

The average students' scores of thinking and innovation skills post-test were statistically significantly higher than that for pre-test. Thus, students' skills of thinking and innovation improved significantly and average scores increased from 3.06 pre-test to 4.10 post-test. This implied that using the online learning system gave an improved rise of $34 \%$.

\section{Discussion}

Online learning systems are clearly important to enhance thinking and innovation skills for higher education learners. The statistical test result was more involved with education technology than the literature review. Students can use online learning systems to significantly enhance their skills in thinking and innovation. Based on the results, an online learning system is recommended with support from mobile technology for student-centered learning, especially for higher education learners that already use online learning and are familiar with mobile devices [50], Anderson \& Rainie [51] predicted that mobile devices will become primary connection tools to the internet. Thus, the trend of mobility, informality and personal ownership will enable students to construct their own understanding and enable learning to go beyond the constraints of time and space $[52,53]$.

\section{Conclusions and future work}

The research presented here designed and developed an online learning system using the SECI process and Moodle to enhance thinking and innovation skills for higher education learners. Findings indicated four sequential learning processes as (1) inspiration, (2) idea selection, (3) invention, and (4) operation. The proposed system allows students to complete their projects by sharing and creating new knowledge 
among team members. Students are able to learn without constraints, and develop their skills in thinking and innovation using online techniques. This system is based on innovative knowledge creation theory in relation to the SECI process, blended with a new Moodle plug-in for assessing students' thinking and innovation skills called "Inno Ed Tools" that claims originality as an online learning system to enhance thinking and innovation skills for higher education. The researcher plans to extend this system as an innovation ecosystem at universities to develop a linkage between students' creativity and business networks and create core value contribution to the country.

\section{Acknowledgment}

This research is supported by Rachadapisek Sompote Fund for Postdoctoral Fellowship, Chulalongkorn University and by Government Budget Research Grant for the year 2016 .

\section{References}

[1] C. Bonk and K.-J. Kim, "The future of online teaching and learning in higher education: The survey says," EDUCAUSE Quarterly Magazine, vol. 29, pp. 22-30, 2006.

[2] U. UK, "Massive open online courses: Higher education's digital moment?," 2013.

[3] G. D. Caruth and D. L. Caruth, "Distance education in the United States: From correspondence courses to the Internet," Turkish Online Journal of Distance Education, vol. 14, 2013.

[4] S. R. Jan, F. Ullah, H. Ali, and F. Khan, "Enhanced and Effective Learning through Mobile Learning an Insight into Students Perception of Mobile Learning at University Level," International Journal of Scientific Research in Science, Engineering and Technology (IJSRSET), Print ISSN, pp. 2395-1990, 2016.

[5] M. Carr, "The Online University Classroom: One Perspective for Effective Student Engagement and Teaching in an Online Environment," Journal of Effective Teaching, vol. 14, pp. 99-110, 2014.

[6] B. Means, Y. Toyama, R. Murphy, M. Bakia, and K. Jones, "Evaluation of evidence-based practices in online learning: A meta-analysis and review of online learning studies," US Department of Education, 2009.

[7] J. K. Tarus, D. Gichoya, and A. Muumbo, "Challenges of implementing e-learning in Kenya: A case of Kenyan public universities," The International Review of Research in Open and Distributed Learning, vol. 16, 2015.

[8] N. R. Council, Education for life and work: Developing transferable knowledge and skills in the 21st century: National Academies Press, 2013.

[9] Binkley M., O. Erstad, J. Herman, S. Raizen, M. Ripley, and M. Runmble. (2014). Partnership for 21st century skills. Available: www.p21.org/.

[10] E. van Laar, A. J. van Deursen, J. A. van Dijk, and J. de Haan, "The relation between 21stcentury skills and digital skills: A systematic literature review," Computers in human behavior, vol. 72, pp. 577-588, 2017. https://doi.org/10.1016/j.chb.2017.03.010 
[11] C. Orús, M. J. Barlés, D. Belanche, L. Casaló, E. Fraj, and R. Gurrea, "The effects of learner-generated videos for YouTube on learning outcomes and satisfaction," Computers \& Education, vol. 95, pp. 254-269, 2016. https://doi.org/10.1016/j.compedu.2016.01.007

[12] W. I. P. Organization, "WIPO IP Facts and Figures 2016," 2016.

[13] A. Davies, D. Fidler, and M. Gorbis, "Future work skills 2020," Institute for the Future for University of Phoenix Research Institute, vol. 540, 2011.

[14] R.-D. Leon, "The future knowledge worker: An intercultural perspective," Management Dynamics in the Knowledge Economy, vol. 3, p. 675, 2015.

[15] D. M. McGUNAGLE, "Meeting Real Work Demands of the Global Economy," $i$ Manager's Journal on Management, vol. 10, p. 36, 2015.

[16] L. Reveszova, "Designing modern informatics education for future managers and advanced users according to their knowledge base," E+ M Ekonomie a Management, p. 186, 2016. https://doi.org/10.15240/tul/001/2016-4-013

[17] C. Pappas, "The Top eLearning Statistics and Facts For 2015 You Need To Know," Récupéré de http://elearningindustry. com, 2015.

[18] H. Lurie and P. Analyst. (2017). A New Normal for Online Learning... and OPMs. Available: http://www.eduventures.com/2017/01/new-normal-online-learning-opms/

[19] Docebo, "eLearning Market Trends and Forecast 2017-2021," 2016.

[20] P. Dillenbourg, S. Järvelä, and F. Fischer, "The evolution of research on computersupported collaborative learning," in Technology-enhanced learning, ed: Springer, 2009, pp. 3-19. https://doi.org/10.1007/978-1-4020-9827-7 1

[21] N. Songkram, "Online Course Design for Creativity and Innovative Skills in Virtual Cultural ASEAN Community," International Journal of Emerging Technologies in Learning, vol. 12, 2017.

[22] I. Nonaka and H. Takeuchi, The Knowledge-creating Company: How Japanese Companies create the dynamics of innovation: Oxford University Press. New York, 1995.

[23] M. D. Alavi and D. Leidner, "Knowledge management and knowledge management systems: conceptual foundations and research issues.," MIS Quarterly, 2001. https://doi.org/10.2307/3250961

[24] S. Gourlay, "Conceptualizing knowledge creation: a critique ofNonaka's theory.," Journal of Management Studies, 2006. https://doi.org/10.1111/j.1467-6486.2006.00637.x

[25] A. Vaccaroa, F. Velosoa, and S. Brusonic, "The impact of virtual technologies on knowledge-based processes: An empirical study," Research Policy, 2009. https://doi.org/10.1016/j.respol.2009.06.012

[26] A. Arora and A. Gambardella, "The changing technology of technological change: general and abstract knowledge and the division of innovative labour.," Research Policy, 1994. https://doi.org/10.1016/0048-7333(94)01003-X

[27] L. D'Adderio, "Configurating software, reconfigurating memories: the influence of integrated systems on the reproduction of knowledge and routines," Industrial and Corporate Change, 2003. https://doi.org/10.1093/icc/12.2.321

[28] J. Birkinshaw, "Why is knowledge management so difficult?," Business strategy review, vol. 12, pp. 11-18, 2001. https://doi.org/10.1111/1467-8616.00161

[29] S. Hammami and M. N. Alraja, "Elearning environment as a facilitator for knowledge creation using SECI model in the context of BA," Journal of Theoretical and Applied Information Technology, vol. 80, 2015.

[30] V. Pertti, Y. Luoma, and A. Naever, "Towards a semantic e-learning theory by using a modeling approach," British Journal of Educational Technology, vol. 37, pp. 445-459, 2006. https://doi.org/10.1111/j.1467-8535.2006.00615.x 
[31] M. Y. Tee and S. S. Lee, "SECI-driven Problem-based Learning for Cultivating Technological Pedagogical Content Knowledge," 2011.

[32] A. Vaccaro, F. Veloso, and S. Brusoni, "The impact of virtual technologies on knowledgebased processes: An empirical study," Research Policy, vol. 38, pp. 1278-1287, 2009. https://doi.org/10.1016/j.respol.2009.06.012

[33] C. Zhao, F. Wang, W. Zheng, Z. Liu, H. Wei, and X. Li, "The Research and Design of Personal Knowledge Management Model Based on Web2. 0," in Knowledge Acquisition and Modeling, 2008. KAM'08. International Symposium on, 2008, pp. 89-92.

[34] Atichart Harncharnchai and Teeraporn Saeheaw, "Share-Review-Practise Spiral Model (SRP) to Enhance Postgraduate Students' Cognitive Skills," in European Conference on Knowledge Management, 2015, p. 349.

[35] M. A. Chatti, R. Klamma, M. Jarke, and A. Naeve, "The Web 2.0 driven SECI model based learning process," in Advanced Learning Technologies, 2007. ICALT 2007. Seventh IEEE International Conference on, 2007, pp. 780-782. https://doi.org/10.1109/ICA LT.2007.256

[36] S. S. Shang, E. Y. Li, Y.-L. Wu, and O. C. Hou, "Understanding Web 2.0 service models: A knowledge-creating perspective," Information \& Management, vol. 48, pp. 178-184, 2011. https://doi.org/10.1016/j.im.2011.01.005

[37] S. M. Hosseini, "The application of SECI model as a framework of knowledge creation in virtual learning," Asia Pacific Education Review, vol. 12, pp. 263-270, 2011. https://doi.org/10.1007/s12564-010-9138-5

[38] Y. Zheng, L. Li, and F. Zheng, "A Conceptual Model of Online Community of Teaching Practice for Preservice Teachers," in Computing and Intelligent Systems, ed: Springer, 2011, pp. 394-400. https://doi.org/10.1007/978-3-642-24010-2 53

[39] C. Sian Lee and R. S. Kelkar, "ICT and knowledge management: perspectives from the SECI model," The Electronic Library, vol. 31, pp. 226-243, 2011. https://doi.org/10.1108/ 02640471311312401

[40] L. Shu, S. Liu, and L. Li, "Study on business process knowledge creation and optimization in modern manufacturing enterprises," Procedia Computer Science, vol. 17, pp. 12021208, 2013. https://doi.org/10.1016/j.procs.2013.05.153

[41] A. Menolli, M. A. Cunha, S. Reinehr, and A. Malucelli, "“Old" theories, "New" technologies: Understanding knowledge sharing and learning in Brazilian software development companies," Information and Software Technology, vol. 58, pp. 289-303, 2015. https://doi.org/10.1016/j.infsof.2014.07.008

[42] M. Haag, Y. Duan, and J. Edwards, "Personal knowledge development in online learning: a model for measuring externalisation, combination and internalisation," KIM2013, vol. 4, p. 132, 2013.

[43] H. Jin, I. Y. Yeo, Y.-G. Kook, B.-H. Lee, and J. Kim, "R\&D Information System to Support Knowledge Creation," in HCI International 2011-Posters' Extended Abstracts, ed: Springer, 2011, pp. 576-579.

[44] Moodle LMS. Available: http://www.lambdasolutions.net/products/moodle-lms/

[45] T. Martín-Blas and A. Serrano-Fernández, "The role of new technologies in the learning process: Moodle as a teaching tool in Physics," Computers \& Education, vol. 52, pp. 3544, 2009. https://doi.org/10.1016/j.compedu.2008.06.005

[46] C. Morosan, M. Dawson, and E. A. Whalen, "Using Active Learning Activities to Increase Student Outcomes in an Information Technology Course," Journal of Hospitality \& Tourism Education, pp. 1-11, 2017.

[47] A. Gunn, "Critical debates in teaching research methods in the social sciences," Teaching Public Administration, p. 0144739417708837, 2017. 
Paper-Design and Development of SECI and Moodle Online Learning Systems to Enhance Thinking ...

[48] D. Saiki and A. D. Adomaitis, "Stimulating learning about textiles with fast fashion in urban and rural settings," International Journal of Fashion Design, Technology and Education, pp. 1-9, 2017.

[49] E. Rapley, "'Seeing the light.'Personal epiphanies and moving towards interpretivism; a researcher's tale of exploring teacher pedagogic practice," Ethnography and Education, pp. 1-19, 2017.

[50] Y. Zidoun, F. Elarroum, M. Talea, and R. Dehbi, "Students' Perception About Mobile Learning in Morocco: Survey Analysis," International Journal of Interactive Mobile Technologies, vol. 10, 2016.

[51] L. Rainie and J. Anderson, "The future of the Internet III," Elon Univeristy, Pew Internet Project, 2008.

[52] M. Sharples, "Big issues in mobile learning," 2006.

[53] L. Naismith, M. Sharples, G. Vavoula, and P. Lonsdale, "Literature review in mobile technologies and learning," 2004.

\section{Authors}

Suparoek Chootongchai, PhD., is currently taking a Post Doctorate in Department of Educational Technology and Communications, Faculty of Education, Chulalongkorn University in Thailand with a sponsorship (Suparoek.C@chula.ac.th).

Noawanit Songkram, PhD., (corresponding author) is an Associate Professor in Department of Educational Technology and Communications, Faculty of Education, Chulalongkorn University in Thailand (noawanit_s@hotmail.com).

Article submitted 15 November 2017. Resubmitted 29 November 2017. Final acceptance 23 February 2018. Final version published as submitted by the authors. 